\title{
Downwards Accountability and Consent in Comprehensive Assistance Missions
}

\author{
Rebecca Lineham ${ }^{1}$
}

\section{Introduction}

Peace operations and comprehensive assistance missions rely heavily on retaining local consent; one critical factor in achieving this is the accountability of the mission to the government and people of the country in which it serves. Mechanisms for oversight and review, and processes for handling local input and dissent, may be one way in which an operation can enhance accountability. The difficulty lies in finding ways to ensure that accountability to local actors is just as rigorous as accountability to donors, sponsors and contributing countries.

\section{Comprehensive assistance missions}

The international community is still experimenting with various types of post-conflict peace support and stabilisation missions. Comprehensive assistance missions - which span both the traditional peace support sectors of law and order, and areas more commonly left to aid partners, such as good governance and economic development - are even more experimental. In our own region, the Regional Assistance Mission to Solomon Islands (RAMSI) is the most prominent example.

On a spectrum of peace operations - with traditional armed peacekeepers interposed between formerly warring parties at one end of the spectrum, and international transitional administrations filling the vacuum of government at the other end - comprehensive assistance missions draw from both ends. On one hand, the range of tasks undertaken by comprehensive assistance missions is almost as broad as that undertaken by an interim administration. On the other hand, like a traditional peacekeeping mission, a comprehensive

1 The views of the author are her own and in no way are intended to reflect New Zealand government policy or the views of New Zealand's Ministry of Foreign Affairs and Trade. assistance mission works at the invitation of and as a partner to an elected government.

Just as traditional peacekeeping must retain the consent of the local people and political leaders, so too must a comprehensive assistance mission work on the basis of an invitation which could be withdrawn at any time. And just as an interim administration must find ways, in lieu of an elected government partner, to build local ownership of the new post-conflict environment, equally must a comprehensive assistance mission concern itself with not undermining or appearing to undermine the authority of the host government at any stage, while preparing local partners to take back full management.

Developing accountable mechanisms for oversight and review of the mission that engage and are owned by local leaders and the local population is one possible way of helping a comprehensive assistance mission to build a stronger consent environment at the outset of the mission. In addition, processes established early on for locals to provide constructive input and for handling dissent and disagreement between the operation, the government and the people may go some way towards averting a destabilisation of the consent environment when dissent inevitably arises later on. In short, when the local population has a means for registering their ideas and their grievances, and feels as though they are receiving a fair hearing, they are less likely to pursue those grievances through less constructive avenues.

\section{Consent environments}

The United Nations Department of Peacekeeping guidelines (1995, p.15) state that

[1] egitimacy is the most important asset of a peacekeeping operation. It rests on an understanding that the operation is just and is 
representative of the will of the international community as a whole rather than some partial interest.

Without external authorisation and endorsement by the appropriate bodies an operation would be considered illegitimate and possibly illegal under international law. However, this definition fails to recognise that an operation's legitimacy comes from two sources - external authorisation and internal consent within the country of operation. Without internal consent an operation would be considered an assault on sovereignty and an intervention tantamount to an act of aggression against the state.

Internal consent - political and popular - forms a critical part of the operation's legitimacy. How to retain the agreement of the host government and the local population often dominates the minds of those who lead and govern peace operations. Without the blessing of the government and the grassroots it is impossible for the operation to exist, let alone have impact. At the most extreme, should a host government withdraw consent, an operation is essentially forced to leave. Even in cases where the government does not withdraw its consent for the operation, but actively undermines the operation, it can be made near impossible for the operation to achieve its goals. Similarly, where government consent exists but the local population does not support the operation, it can become the target of attack, forcing it to abandon certain functions, and be actively resisted by local partners, preventing the mission from achieving any sustained change.

Changes to the internal consent environment are common in all peace operations. The tide of support falls and rises as the operation moves through various phases. This is particularly the case in transitional administrations and comprehensive assistance missions. The changes experienced by the recipient country can be sudden and dramatic, and may be unwanted by the less scrupulous in society. Misunderstanding, wilful or genuine, of the operation's intent can also affect levels of consent. Criticism and dissent can be disheartening for an operation set up with the best of intentions. They can be equally threatening to the operation's existence, more so when the criticism comes from quarters of influence. Since much of the most unsettling criticism is made by self-serving dissenters to mask expedient objectives, it can be tempting for missions to bypass the actual criticisms and move directly to trying to improve the consent environment by diplomatic means. There can be definite value in working that route. At the same time, not addressing the actual criticisms can have risky consequences. Albeit that much of the criticism is made for illegitimate reasons, it is often based on some perception of legitimate cause, and there is often at least some legitimate criticism too. Leaving those grievances unaddressed leaves room for dishonest actors to manipulate the situation and create a larger public grievance. It also prevents the mission from learning and recognising the inevitable mistakes and weaknesses that any mission will have.

If an operation can find ways to address criticisms before they become major issues of public concern, it may be more likely to avoid some of the tidal shifts in the consent environment. This will also help to prevent self-serving dissenters using public forums to raise illegitimate criticisms and misleading the public. This is the point at which the operation's mechanisms for accounting to the local population come into play. The better equipped an operation is to receive, process and respond to suggestions, complaints and grievances from the local population, the more likely it is to retain its local legitimacy and consent for longer, and be effective.

\section{Downwards accountability}

Most local criticism of international assistance and peace operations has tended to focus on the perception - rightly-or wrongly-based - that the operation wields far too much power with too little control by locals. Enter the mechanisms of democratic accountability: the accounting for one's actions and decisions to the people they affect, and enabling the people to participate in decision making and governance. These mechanisms are primarily concerned with preventing excess of power.

The Brahimi report on peacekeeping (2000, p.2) noted the importance of holding individual officials at headquarters and in the field accountable for their performance'. The techniques for doing so are highly underdeveloped in all international operations. Even where operations have developed reporting, review and complaints mechanisms they have largely been disempowered by being kept internal. Performance review and oversight is critical to enhancing the transparency of international operations. 
The practice of democratic accountability is important to international peace operations for many reasons, not least because its manifestations - transparency, checks and balances on power, local participation, and local ownership of governance - are likely to confer greater legitimacy on the operation. There is also a strand of thought, with more than a little credibility, that it is inconsistent with the intended ends of a peace operation for it not to be a bastion of democracy itself.

In a functioning democracy, democratic accountability is assured through the processes established to practice that democracy (most usually through representative politics and elections). Through the practice of participatory decision making and representative politics, legitimacy for the governing structure in the country derives from the people. How to create mechanisms of democratic accountability in a comprehensive assistance mission, however, is less straightforward. All international assistance or administrative missions have struggled to find a 'downwards' balance to their ultimately 'upwards' accountability to donors and authorising bodies. The struggle is heightened for the comprehensive assistance mission, which must constrain itself, as much as possible, to working through its government partner, and not appearing to establish a parallel system of government. It is also integral to the development objectives of a comprehensive assistance mission that it model local empowerment and ownership by being fully and firstly accountable to the local partners it is seeking to develop.

Consultation with and involvement of the local community is one of the most important means for an operation to build local ownership, and identify problems and effective solutions. The United Nations handbook Multi-Disciplinary Peacekeeping (United Nations Department of Peacekeeping Operations, undated, pp.10-11) notes that:

In its peacekeeping and peace-building efforts, the operation is best advised to work through existing local authorities and community elders and its peace initiatives must be closely tailored to indigenous practices of conflict management, provided these do not contradict accepted international standards of human rights and humanitarian law.

The question, however, of who in the local community a comprehensive assistance mission is to consult, and how, does not have an obvious answer. The issue is particularly sensitive since any community consultation undertaken by the operation must be done without being seen as undermining the operation's partnership with the government, or the government's sovereignty. Compounding the problem is the fact that often the government in a fragile state does not have well-developed mechanisms by which it can itself receive public input and monitor public opinion. If an operation was to offer the community accessible methods for participation it may attract the sort of input that should be more appropriately addressed to the government.

Rather than creating a centralised - and therefore more seemingly 'parallel' - system of democratic accountability, an operation can institute a range of processes for ensuring that local critique can be received and replied to. Through local consultation, input and feedback - using mechanisms such as involvement of locals in implementation planning, internal and transparent mission investigatory processes, a mission ombudsman, and a stronger governance role by the authorising body - a comprehensive assistance mission may find many means for enhancing its accountability and thereby its legitimacy and credibility.

\section{Involvement in operation and imple- mentation planning}

One of the sources of local criticism of comprehensive assistance missions is that those in charge of managing the operation do not understand the local environment, yet are in sole charge of deciding what should be implemented, when and how.

One way of gaining a greater degree of local ownership in a peace operation is to consult over the appointment of the operation's key managers. Rather than having the authorising body alone appoint a head of mission, some form of consultation and agreement with the host government over such high-level appointments would get better buy in and local support. This has been used before - in the United Nations Transitional Administration in Eastern Slavonia (UNTAES) the head of the mission, the special representative of the secretarygeneral, was appointed in consultation between the two parties (Serbia and Croatia) and the Security Council.

Another method is the creation of joint administrative structures responsible for implementing aspects of the 
operation's mandate. In Kosovo this was done by way of the Joint Interim Administrative Structure (JIAS), which was given policy guidance by an Interim Administrative Council made up of four United Nations Interim Administration Mission in Kosovo (UNMIK) representatives and four local people. The JIAS had the power to make recommendations to the special representative, who could either accept the recommendations or otherwise had to explain the reasons for not accepting them. In East Timor, prior to the formation of the first government, a Transitional Administrative Council, consisting of four representatives from the United Nations Transitional Administration in East Timor (UNTAET) and four local personnel, gave policy guidance to the East Timor Transitional Administration. In UNTAES in Eastern Slavonia, the head of the operation, the transitional administrator, established a Transitional Council consisting of one representative each from the government and three local population groups (Croat, Serb and minorities). It was advisory only, and the transitional administrator was not required to obtain consent for decisions, in order not to risk being held captive to vetoes. UNTAES also established 13 Joint Implementation Committees consisting of Serb and Croat representatives, covering a range of sectoral issues such as the refugee return, health and education.

The value of each of these models is the high-level engagement by locals in the direction and management of the operation. Each model is workable for a comprehensive assistance mission.

\section{Oversight of operation personnel by internal mission processes}

A second, and not insignificant, source of criticism are the actions of mission personnel. It has now been well documented in every peace operation globally that peacekeepers and their civilian comrades have been involved in illegal, immoral and insensitive activity. Peacekeepers have, unfortunately, been involved in prostitution, smuggling, slavery and even murder. This immediately detracts from the credibility of an operation. But even when an individual's actions are of less obvious malevolence the operation can be brought into serious disrepute. Relationships between expatriates and locals that are dishonest or go sour, cultural insensitivity such as heavy drinking, inappropriate clothing and unsafe driving, all are lightning rods for criticism from the local population. While most missions do their best
- some better than others - to stamp out and control such behaviour, it is almost inevitable that such activity will be engaged in by a few.

When the actions of a few disrupt the good name of an operation, it is more likely that it will face challenges to the immunity of its personnel. A local community needs to see that, just as is the case for them in their own justice system, wrong behaviour is investigated, judged and punished.

While the military forces have generally well-developed processes for investigating reports of such activity, there is almost no equivalent for the civilians in a mission. With civilians now numbering many more than military personnel, particularly in a comprehensive assistance mission, this exposes a glaring gap in the accountability of an operation. Even where an operation does have some form of internal investigatory and censure process for individuals found to be bringing the operation into disrepute, this is usually closed off to locals, internal and anything but transparent.

Comprehensive assistance missions could greatly benefit from having an accessible complaints and investigatory mechanism within the operation for handling complaints about such activity. In order to be properly accountable, such a process would require formal hearings, powers of investigation, and the authority to make binding judgements, including repatriation of individuals for prosecution in their home territory and the waiving of immunity for an individual who has acted illegally during his/her free time. Decisions could then be reported to the local community. Rather than the operation appearing to be less credible because of the actions of a few 'bad eggs', it would develop an accountability chain that made it very clear to the local population that the operation would not tolerate any kind of misbehaviour by its personnel. Its legitimacy and credibility are likely to be improved.

While all operations routinely require immunity from the domestic law in the host country for personnel in order to take place, this immunity is not absolute in that it can be waived by the Head of the Mission concerned. It is also not intended to confer complete immunity from any legal system, but only from the host country. It is premised on the false assumption, that there will always be some legal system which would have jurisdiction. In regard to lifting immunity in the country of the 
actual peace operation, this would only be done if the host country's legal system was considered appropriate to be able to deal with the allegations concerned. In virtually all circumstances, that is unlikely. The real problem is therefore that the legal processes somewhere else, which should in theory 'stand behind' immunity from the law in the country of operation, either do not confer extra-territorial jurisdiction, or there are major practical difficulties of ever making it work (such as gathering evidence) (Ladley, 2005).

So, at least some practical and visible accountability (by waiver in some cases, and by external prosecution in others) needs to be clear to the local population if this critical element of accountability is to be believed. Ensuring that operation personnel do not have impunity from all law (i.e., that contributing countries have the ability to extend extra-territorial jurisdiction over all members of its assistance mission) is very important. At the moment, very few countries have the legal provisions to do so. If an individual is repatriated and tried in their home country for a criminal offence in the country of operation, the results of such trials and hearings need to be fed back to the local community.

\section{Oversight by a jointly-directed om- budsman's office}

In addition to internal mission processes, a more independent process for investigating complaints would also help improve accountability. In a comprehensive assistance mission - where the operation works in partnership with the host government - such a mechanism, jointly headed by an independent government appointee and an independent appointee appointed by the authorising body, could also contribute towards building local capacity and political responsibility and ownership. The mechanism could operate in a similar way to an ombudsman's office - accepting broader complaints relating to operation policy, or to individuals where the complainant was not satisfied with the outcome of the internal mission investigatory process.

The establishment of independent ombudsman's offices, mandated to address concerns with a peace operation, is becoming more common and has been recommended by the United Nations secretary-general, in a report on the protection of civilians in armed conflict. Described by one researcher, Frederick Rawski (2002, p.116):
Partly in response to growing concerns about abuses by UN staff and the lack of transparency of UN field missions generally, Ombudsperson offices have been the main vehicle established at the mission level to resolve claims of abuse. ... In theory these institutions ensure that the mission as a whole acts in a way that is consistent with its mandate, and with international human rights standards generally.

Ombudsman's offices have been established during a number of operations, including in Bosnia, Kosovo and East Timor. Each one has had differing mandates. The Bosnian ombudsman was restricted to examining the actions of local civil administration institutions only, and could not address the actions of the international operation. In Kosovo, the ombudsman's office is able to address all activities and processes (local and international) except for the NATO-led civilian policing component of the operation, KFOR. In East Timoro the ombudsman was authorised to address action by any international or local institution.

The most openly available information relates to the Kosovo ombudsman's office. The Kosovo ombudman's office was established to:

promote and protect the rights and freedoms of individuals and legal entities and ensure that all persons in Kosovo are able to exercise effectively the human rights and fundamental freedoms safeguarded by international human rights standards, in particular the European Convention on Human Rights and its Protocols and the International Covenant on Civil and Political Rights. (Ombudsperson Institution in Kosovo, 2004)

Proving the local appetite for such mechanisms, in the year July 2003-June 2004, 4,000 people contacted the Kosovo ombudsman and 420 cases were provisionally registered. The ombudsman in Kosovo has also written a range of reports on wider issues, including the division of powers in UNMIK and the legality of total immunity for UNMIK personnel. The publicly available reports from the Kosovo ombudsman provide a real insight into the types of concerns and issues facing the local population, greatly enhancing the transparency of the operation.

Something similar - a Joint Steering Committee - was established as part of Australia’s original Enhanced 
Cooperation Program (ECP) in Papua New Guinea. The Joint Steering Committee of the ECP consisted of representatives from both Australia and Papua New Guinea. It provided an oversight mechanism that could respond to local petitions and complaints by allowing that '[a]ny member of the Joint Steering Committee may put in writing any complaint regarding the conduct of a Designated or Related Person and regarding implementation of Article 8 [relating to jurisdiction]. ${ }^{\text {1 }}$ That complaint then became the subject of consultation between Papua New Guinea and Australia through the Joint Steering Committee.

Whichever means is used, providing a dedicated and independent mechanism by which the local population, at any time, can register serious complaints about the activities or processes of the operation would markedly improve the democratic accountability and transparency of any mission.

\section{Oversight by the operation's authorising body}

The oversight of an operation is one of the first things decided when the international community considers how best to establish a peace mission of any kind. Ultimately, every peace operation is overseen by the body or organisation which authorises the mission - be it the United Nations or a regional body such as NATO or the Pacific Islands Forum (as in RAMSI's case).

Some bodies are better experienced than others in overseeing peace operations. The United Nations, for example, oversees multiple peace operations which must report to the Security Council periodically as determined by the operation's mandate. Reporting to the UN Security Council is supposed to allow an opportunity for review and guidance of the operation. In doing so, the Security Council has at its side the UN Department of Peacekeeping Operations, which continuously studies best practice and lessons learnt from each operation. Other bodies, particularly some regional bodies, are less experienced.

The way in which an operation is overseen is vitally important to how it operates. Strong governance will help the mission to stay on task and prevent any gradual

1 Article 9(5), Joint Agreement on Enhanced Cooperation between Australia and Papua New Guinea, 30 June 2004 (entry into force: 13 August 2004). 'mission creep'. Ultimately, the oversight body is the final arbiter of changes to and withdrawal of a mission. Currently it is usual, however, that the oversight body is only in receipt of reporting from the mission itself. While a host government may make representations to that oversight body, there is little ability or process for the authorising body to receive regular reporting from the host government and local population.

The level and quality of oversight of peace operations (even by the UN Security Council) has occasionally given rise to suggestions that the UN's now inoperative Trusteeship Council be revived. The Trusteeship Council, a modern equivalent, or a replication of its powers in a committee of a regional body required to oversee a peace operation, may assist in more thorough oversight of such operations.

The UN Trusteeship Council had three primary responsibilities: to consider reports from the administering power; to accept petitions from inhabitants; and to provide for periodic visits to the region under trusteeship. In addition, the Trusteeship Council was empowered to formulate questionnaires on the political, economic, social and educational advancement of the inhabitants of the trust territory. These questionnaires, reports, petitions and visits would form the basis of an annual report to the General Assembly regarding the trusteeship.

Adoption of the functions of the Trusteeship Council by a standing committee of an operation's overseeing body would better ensure that those who oversee operations are able to receive reporting from the operation and make changes, hear from the people of the country, including the host government, and undertake their own research. This combination of oversight functions immediately provides some balance of operation accountability to its masters with accountability to the local people and government. The avenue of local petition direct to the oversight body would clearly be one of last resort - lest the oversight body be inundated with spurious or self-serving appeals. But should legitimate and high-level differences of opinion arise, particularly between the host government and the peace operation, the oversight body would be well placed and qualified to act as an interlocutor. 


\section{Conclusion}

With the addition of the sorts of tried and tested oversight and investigatory mechanisms discussed above - a fully empowered oversight committee in the authorising body, a jointly-staffed ombudsman's office, an investigatory and complaints mechanism within the operation, and joint implementation/management consultative committees - a comprehensive assistance mission would have many more processes for addressing issues of dissent. Should a consent environment start to destabilise, any and all of those mechanisms should be able to appropriately address the concerns and prevent a larger public grievance from forming and unsettling the operation's consent environment.

Comprehensive assistance missions have been shown to be valuable instruments of change in post-conflict environments; with their 'whole of government' approach, they are able to provide a coordinated approach to security and development. To remain credible and supported they must show that they are willing to accept input, feedback and critique from the local population. This paper has examined but a few of the potential mechanisms for improving the downwards accountability of a mission. Others that could be explored include performance reviews that relate an operation's mandate directly to the individual performance assessments of operation personnel, jointly developed and managed exit strategies, and flexible approaches to operation structures that can better take account of local input. Rather than shutting off the avenues of critique - leaving public media the main vehicle - an operation which is truly accountable to the people will offer simple processes for hearing the people's voices, and will demonstrate an honest willingness to respond even when it means self-censure, admitting fault and making changes. Regrettably, it has been shown that by not having such avenues, even the most supported operation faces unwarranted and disproportionate condemnation.

\section{References}

Brahimi, L. (2000) Report of the Panel on United Nations Peace Operations [Brahimi Report], A/55/305-S/2000/809, presented to the United Nations General Assembly and Security Council, 55th session, 21 August

Caplan, R. (2004) 'Partner or Patron? International civil administration and local capacity-building', International Peacekeeping, 11 (2), Summer
Caplan, R. (2005) 'Who Guards the Guardians? International accountability in Bosnia', International Peacekeeping, 12 (3), Autumn, pp.463-76

Chesterman, S. (2003) You, the People: the United Nations, transitional administration, and state-building. Project on transitional administrations - final report, International Peace Academy

Ladley, A. (2005) 'Peacekeeper Abuse, Immunity and Impunity: The Need for Effective Criminal and Civil Accountability on International Peace Operations', Politics and Ethics Review, 1(1), pp. 81-90

Ombudsperson Institution in Kosovo (2004) Fourth Annual Report 2003-2004 addressed to the special representative of the secretary-general of the United Nations

Rawski, F. (2002) 'To waive or not to waive: immunity and accountability in UN peacekeeping operations', Connecticut Journal of International Law, 18, pp.103-32

United Nations Department of Peacekeeping Operations (undated), Multi-Disciplinary Peacekeeping: Lessons from Recent UN Experience

United Nations Department of Peacekeeping Operations (1995) General Guidelines For Peacekeeping Operations, New York

United Nations Department of Peacekeeping Operations (2003) Handbook on United Nations Multidimensional Peacekeeping Operations, New York, December

United Nations Secretary-General (1999) Report of the Secretary-General to the Security Council on the protection of civilians in armed conflict, S/1999/957

Rebecca Lineham works as a foreign policy officer at the Ministry of Foreign Affairs and Trade. She is currently posted in Honiara, Solomon Islands. After leaving Amnesty International she undertook a Master of Strategic Studies at Victoria University of Wellington's School of Government, focusing on peacekeeping, conflict resolution and terrorism. In 2006 she was awarded the inaugural Prime Minister's Prize in Strategic Studies, and also the Holmes Prize for her research. 
BEING ACCOUNTABLE: Voluntary

Organisations, Government Agencies and Contracted Social Services in New Zealand

\section{An Institute of Policy Studies publication by Jo Cribb}

Governments in New Zealand and many other countries rely heavily on voluntary (or non-profit) organisations to deliver vital social services. However, the current contracting and funding mechanisms used to purchase such services on behalf of citizens are problematic for both funding bodies and providers.

Being Accountable: Voluntary Organisations, Government Agencies and Contracted Social Services in New Zealand explores the contracting relationship from the perspective of voluntary organisations. The central issue, it is argued, does not lie in the use of contracts per se, but in the relationships and practices used to generate them.

Published - November 2006

Format - A5 Paperback, pp 195

ISBN - 1-877347-15-9

Price $-\$ 25.00$ (including P\&P within New Zealand)

To have a copy of Being Accountable: Voluntary

Organisations, Government Agencies and Contracted Social Services in New Zealand and an invoice sent to you, please email, phone, fax or mail your order to:

\section{Institute of Policy Studies}

Victoria University of Wellington

Email ipos@vuw.ac.nz

Telephone +64 44635307

Fax +64 44637413

P0 Box 600, Wellington

New Zealand

\section{IMPLICATIONS OF POPULATION} AGEING: Opportunities and Risks

\section{An Institute of Policy Studies publication edited by Jonathan Boston and Judith $A$. Davey}

Population ageing, both globally and in New Zealand, is often seen in negative terms. But it can also be viewed positively - as an opportunity, an achievement of human civilisation and thus something to celebrate. The contributors to the 14 chapters in Implications of Population Ageing: Opportunities and Risks explore New Zealand's changing demography and examine many of the policy implications of population ageing, including those impinging on fiscal management, income support and the labour market.

The crucial message is that while population ageing undoubtedly poses serious challenges, it also generates many opportunities and possibilities, and the recognition of these will be critical for New Zealand's long-term economic and social success.

Published - October 2006

Format - B5 Paperback, pp 388

ISBN - 1-877347-14-0

Price - \$39.90 (incl P\&P within NZ)

To have a copy of Implications of Population Ageing: Opportunities and Risks and an invoice sent to you, please email, phone, fax or mail your order to

Institute of Policy Studies

Victoria University of Wellington

Email ipos@vuw.ac.nz

Telephone +64 44635307

Fax +64 44637413

P0 Box 600, Wellington

New Zealand 